\title{
A quantitative risk assessment methodology for construction project
}

\author{
VISHAL KUMAR GUPTA ${ }^{1, *(0)}$ and JITESH J THAKKAR ${ }^{2}$ \\ ${ }^{1}$ RCG School of Infrastructure Design and Management, Indian Institute of Technology, Kharagpur 721302, \\ India \\ ${ }^{2}$ Department of Industrial and Systems Engineering, Indian Institute of Technology, Kharagpur 721302, India \\ e-mail: vishal.vishu.kumar@gmail.com; jtiitkgp@gmail.com
}

MS received 13 July 2017; revised 5 November 2017; accepted 18 January 2018; published online 26 June 2018

\begin{abstract}
It is observed that most of the infrastructure projects fail to meet their cost and time constraints, which will lead to a low return on investment. The paper highlights that the present risk management tools and techniques do not provide an adequate basis for response selection in managing critical risks specific to infrastructure projects. This paper proposes a risk quantification methodology and demonstrates its application for an industrial construction project. A case study is used to present an application of the proposed risk management methodology to help organisations efficiently choose risk response strategy and allocate limited resources. The research adopts an integrated approach to prioritize risks using Group Technique for Order Preference by Similarity to Ideal Solution (GTOPSIS) and to quantify risks in terms of overall project delays using Judgemental Risk Analysis Process (JRAP), and Monte Carlo Simulation (MCS). A comparison between the results of qualitative risk analysis using GTOPSIS and quantitative risk analysis i.e., JRAP and MCS is presented. It is found that JRAP along with MCS could provide some powerful results which could help the management control project risks. The crux of this paper is that the risks are highly dependent on project schedule and the proposed methodology could give a better risk priority list because it considers slackness associated with the project activities. The analysis can help improve the understanding of implications of specific risk factors on project completion time and cost, while it attempts to quantify risks. In turn, this enables the project manager to devise a suitable strategy for risk response and mitigation.
\end{abstract}

Keywords. Construction project; project risk management; judgmental risk analysis process (JRAP); group technique for order preference by similarity to ideal solution and sensitivity analysis (GTOPSIS).

\section{Introduction}

There is a need of huge investment on Infrastructure in India, not only to provide basic requirements to the people of India but also to sustain a healthy economic growth for the country. Be it roads, water supply, power, sewers, housing, railways so on and so forth, development of every such thing require a large amount of money to be invested. Generating finances for such project is itself a difficult task. The government of India had planned to spend of around INR 50 trillion for the $12^{\text {th }}$ five-year plan (2013-17) [1]. While infrastructure has been driving economic growth in India, it has been noticed that out of 561 projects 242 projects are delayed as on $1^{\text {st }}$ January 2012 [1]. Any delay in projects relating to infrastructure facilities upsets the economic feasibility of the projects that depend on them [2]. It has been noted by Kalady [1] that the industryspecific projects such as in railways, road and highway, Shipping and Ports and Steel have time and cost overrun as

*For correspondence
98\% (83\%), 85\% (54\%), 95\% (31\%) and 81\% (19\%), respectively. This clearly indicates that most of the projects are failing to achieve their planned objectives in terms of cost and time.

As evident from time and cost overrun figures, risk management processes, especially in Indian construction companies, have huge shortcomings. Also, there is a need for better portfolio management of risks and opportunities. This research is an attempt to develop an integrated methodology for better risk management process, getting its motivation from the aforementioned issue of high cost and time overruns.

Due to the presence of risks and uncertainties, inherent in different stages of projects, many construction projects have failed to achieve the determined project objectives in terms of time, cost and quality. Construction projects are one-off the endeavours with many unique features such as long period, complicated processes, abominable environment, financial intensity and dynamic organisational structures and such organisational and technological complexity generates enormous risks like bureaucracy, delay in 
land acquisition, financial instability, etc. While risks cannot be eliminated completely, successful projects are those in which risks are effectively managed [3].

According to Project Management Institute [4], Risk Management is one of the nine key areas of any project, which determines the degree of success or failure of any project. Within the currently accepted view of project management as a life cycle process, project risk management (PRM) can also be seen as a process that goes on in the project from its conception through its planning, execution and control phases up to its completion and closure [5]. An awareness of the status of the project through reliable forecasts helps keep the project on schedule [2]. A significant improvement in project management performance can be achieved by providing greater attention to all risk management processes [6].

This research sets two motivations. First, to present that the literature lacks efforts on quantitative assessment of risks and selection of an appropriate risk response for infrastructure projects (see section 2). It is expected that the methodology proposed by this research can assist practising managers to gain greater insights into the critical high-risk areas needing immediate attention. A second motivation is derived from the fact that no prior research has quantified the risks and risk response for an Indian construction project. This study intends to set the platform for future research in the area of risk assessment and selection of risk response strategy for the construction industry. The insights evolved through an application of the proposed methodology to a case of Indian construction industry draws an attention of practitioners towards key areas of improvements. It is expected that this will facilitate the decisionmakers to evolve better understanding in their respective areas of operations and evolve risk minimization and mitigation plans.

In view of the motivations cited above, the research reported in this paper proposes a quantitative risk assessment and risk response selection methodology for construction industry. However, in the process to do so, first the critical risks in a construction industry were identified, and their significance in various aspects of construction project were assessed. Finally, applicability of the proposed method was demonstrated using a real-life case.
The remainder of the paper is structured as follows. Section 2 contains literature review. Section 3 describes the methodology adopted for this research. Section 4 presents data collection and case study. Section 5 provides results and discussions along with sensitivity analysis. Finally, section 6 draws the conclusions from our work; followed by section 7 that deals with further scope.

\section{Literature review}

Project Management Institute in PMBOK [4] states Project Risk Management includes identifying, analysing, and responding to project risk. It includes maximising the results of positive events and minimising the magnitudes of adverse events.

Risk assessment has number of objectives [7], It gives an overview of the general level and pattern of risk facing the project; it focuses management attention on the high-risk items in the list; it helps to decide where action is needed immediately, and where action plans should be developed for future activities; and it facilitates the allocation of resources to support management's action decisions. Kutsch and Hall, [8] state that beyond PMI standard there is a number of other "best practice" project risk management process such as British Standard Institute (2000), Office of Government Commerce (2007), UK Association of Project Management (2005). An overview of main project risk management processes is presented in table 1 .

From the literature review, it is clear that there are two general approaches widely used in project risk analysis: qualitative risk analysis and quantitative risk analysis.

Qualitative risk analysis: Qualitative risk analysis is a process of prioritising risks for further analysis or action by assessing and combining their probability of occurrence and impact [4]. Qualitative risk analysis is usually fast and cost effective means for establishing priority for risk response and prepares the foundation for quantitative risk analysis. Commonly used methods for qualitative risk analysis mentioned are 'Risk probability and impact assessment', 'Probability and impact matrix' and 'Experts judgment'

Table 1. Best practice PRM process and organizations [8].

\begin{tabular}{|c|c|c|c|}
\hline Major Steps In Project Risk Management & PMBOK - PMI & OGC & PRAM - APM \\
\hline Planning & Risk Management Planning & Context & $\begin{array}{l}\text { Focus } \\
\text { Define }\end{array}$ \\
\hline Identification & Risk Identification & Risk Identification & $\begin{array}{l}\text { Identify } \\
\text { Structure }\end{array}$ \\
\hline Analysis & Risk Analysis & $\begin{array}{l}\text { Assess - Estimate } \\
\text { Assess - Evaluate }\end{array}$ & $\begin{array}{l}\text { Estimate } \\
\text { Evaluate }\end{array}$ \\
\hline Response & $\begin{array}{c}\text { Risk Response Planning } \\
\text { Risk Monitoring And Control }\end{array}$ & $\begin{array}{c}\text { Plan } \\
\text { Implement } \\
\text { Communicate }\end{array}$ & $\begin{array}{c}\text { Plan } \\
\text { Ownership } \\
\text { Manage }\end{array}$ \\
\hline
\end{tabular}


Table 2. Classification of risk response.

\begin{tabular}{|c|c|}
\hline $\begin{array}{l}\text { Risk } \\
\text { Avoidance }\end{array}$ & $\begin{array}{l}\text { Involves changing the project management plan to eliminate the threat entirely [4]. Example of risk avoidance is: a } \\
\text { contractor not placing a bid or the owner not proceeding with project funding are two examples of eliminating the } \\
\text { risk totally [35]. }\end{array}$ \\
\hline Risk Transfer & $\begin{array}{l}\text { Risk transfer requires shifting some or all the negative impact of a threat, along with ownership of the response, to a } \\
\text { third party. Transfer of risk simply gives another party responsibility of its management; it does not eliminate it [4]. } \\
\text { (e.g. Insurances, Guaranties, Sub Contracting) }\end{array}$ \\
\hline $\begin{array}{l}\text { Risk } \\
\quad \text { Mitigation }\end{array}$ & $\begin{array}{l}\text { Implies a reduction in the probability and/or impact of an adverse risk event to be within acceptable limit. It calls for } \\
\text { early measures to reduce the probability or impact of a risk [4]. (Reduce the probability of occurrence, Reduce } \\
\text { probable consequences) }\end{array}$ \\
\hline $\begin{array}{l}\text { Risk } \\
\text { Acceptance }\end{array}$ & $\begin{array}{l}\text { This strategy is adopted because it is seldom possible to eliminate all threats from a project [4]. This strategy indicates } \\
\text { that the project team has decided not to change the project management plan to deal with a risk, or is unable to } \\
\text { identify any other suitable response strategy. }\end{array}$ \\
\hline
\end{tabular}

Quantative risk analysis: Quantitative risk analysis is a process of mathematically analysing the impact of identified risk on overall project objectives [4]. Quantitative risk analysis is performed on risks that have been prioritised using qualitative risk analysis process, as those are potentially the ones which are substantially affecting the projects. The main quantitative techniques in current use are 'Sensitivity analysis', 'Modelling and Simulation' and 'Decision trees' [4]. Among this Monte_Carlo Simulation is more preferred.

Risk response: Risk response is a process of developing options and actions to augment opportunities and to minimise the threat to project objectives [4]. A response is any action or activity that is implemented to deal with a specific risk or combination of risks [9]. Risk responses may be classified into four different categories (risk avoidance, risk transfer, risk mitigation and risk acceptance) as summarised in table 2 .

A rigorous risk analysis is needed before any project is ventured upon in order to guarantee its financial and technical feasibility. It can help to sort out unsound projects and get minds working together early enough to overcome difficulties. An improved understanding of the project risks leads to the formulation of more realistic plans in terms of cost estimates and programmes. Knowing the extent of the possible impact that may be caused by the contingent factors, the parties involved can seek for better allocation of the risks through the agreement of suitable contract clauses, or insurance, or training, or securing or other risk response measures. A positive and rational risk-taking attitude will result from a carefully prepared risk analysis as the risktakers will know where they stand. From another aspect, risk analysis is very important, because the analysis works effectively in the negotiation process with the government. Table 3 presents a review of risk assessment literature and its development during the past and recent years.

Some of the limitations of the present project risk management processes are reported in the literature are as follows:

- The most risk assessment studies focused mainly on delivering risk ratings, and there is a need of comprehensive methodology that could help the management in avoiding construction time overrun [10].

- Risks are different for a different phase of the project, so, one-time risk analysis is not enough. Moreover, the severity of risk pertaining to a project varies from activity to activity [11].

- Risk response selection is mostly made by personal judgement, and there is no systematic approach to select the optimum response to the project risks [12].

- There is a need to provide the user with effective tools and techniques for assessing the risk response actions in the area of risk management [13].

- The Monte-Carlo Simulation technique is commonly used to forecast overall project cost and associated achievable probability based on each activity's cost probability distribution [14]. However, it is not designed to support preventive decisions on individual risks.

A critical review of the literature has revealed that one of the limitations of PRM is "Risk response selection" which is mostly done by personal judgement and there is no systematic approach to select the optimum response to the project risks. Ali Hatefi et al state that "there is still a significant gap in the literatures in quantification of project risks. There is a need to provide the user with an effective tools and techniques for assessing the risk response actions in the area of risk management" [13]. Moreover, the literature survey reveals that most of the risk analysis tools and techniques end up prioritising risks without giving us any clue of potential losses in terms of cost or time delays.

However, the recent trend in literature shows a heightened interest in developing quantitative risk analysis and response selection methodologies. Mariana and Vizzini presented a deterministic technique for assessing and preventing project risks, by determining the risk of the Work Progress Status [15]. Zhang constructed an optimisation model for selecting risk response strategies considering the expected risk loss [16]. Gladysz et al proposed a PERTbased mixed linear programming model that supports timerelated project risk response [17]. Nguyen et al proposed a decision-making tool to help the project manager select a 
Table 3. A review of risk assessment literature.

\begin{tabular}{|c|c|}
\hline Reference & Contribution/Focus \\
\hline Ben-David and Raz, 2001 [36] & $\begin{array}{l}\text { It presents a model that integrates project work, risk events, and risk mitigation actions and } \\
\text { their effects into a comprehensive framework. }\end{array}$ \\
\hline Prasanta Kumar Dey, 2001 [11] & $\begin{array}{c}\text { Presents quantitative approach to construction risk management through analytic hierarchy } \\
\text { process and decision tree analysis. }\end{array}$ \\
\hline Hillson, 2002 [37] & $\begin{array}{l}\text { Extends the scope of the risk process to include opportunity management explicitly arguing } \\
\text { that the tools and techniques available to risk practitioners seem to focus attention only on } \\
\text { the negative side of risk. }\end{array}$ \\
\hline Ward and Chapman, 2003 [38] & $\begin{array}{c}\text { The paper reasons that a focus on 'uncertainty' instead of risk could improve project risk } \\
\text { management. The paper providing a different perspective, including, but not limited to, an } \\
\text { improved focus on opportunity management. }\end{array}$ \\
\hline
\end{tabular}

Prasanta K Dey and Ogunlana, 2004 [39] Studies usefulness of risk management tools \& techniques in BOT projects through literature reviews and develops a model for the selection risk management process for BOT projects.

Ali Hatefi, Seyedhoseini, and Noori, 2007 Reviews the tools \& techniques for risk response action assessment \& selection, especially [13]

Kasap and Kaymak, 2007 [40] in the project management environment.

Reviews various methods of risk identification like document review, brainstorming, checklist technique, interviewing etc. It stresses upon the importance of risk identification for better risk management.

J. Zhang, Cai, Li, and Mu, 2011 [41]

Fang, Marle, and Zio, 2011 [19]

Developed an AHP model is established to prioritize the risk factors in highway tunnels. Proposed a framework of analysis for supporting decision making in project risk response planning. A genetic algorithm is used as a tool for selecting response actions and allocating budget reserves.

Prasanta Kumar Dey 2012 [42]

Proposed an integrated analytical framework for management of project risks using combined MCDM technique and decision tree analysis.

Nguyen et al, 2013 [18]

Proposed a decision-making tool to help the project manager select the best risk response strategy. They named the methodology as ProRisk which uses the notions of risk scenario, treatment scenario, and project scenario to determine the impacts of possible risks (combined or not) with preventive and/or corrective actions.

Oke and Ugoje, 2013 [43]

Acebes et al, 2014 [44]

Shanmugapriya \& Subramanian, 2015

Pfeifer, Barker, Ramirez-Marquez, \& Morshedlou, 2015 [46]

Gładysz, Skorupka, Kuchta, \& Duchaczek, 2015 [17]

Zhang, 2016 [16]

Wang \& Yuan, 2016 [47]

Zhao, Hwang, \& Gao, 2016 [48]

Mohammadipour \& Sadjadi, 2016 [49]

Proposes a framework the assessment of rework cost of selected building projects in Nigeria. Integrated EVM with risk management using common EVM indicators and MCS, this allows project managers to detect negative and positive aberrations from planned values, corresponding to cumulative positive or negative cost/schedule buffers.

Here researchers have adopted structural equation model to evaluate the relationship between enablers of framework European Foundation for quality management (EFQM), so that quality performance of Indian construction projects could be improved.

They proposed a genetic algorithm to identify those tasks which are mainly responsible for project risk that lead to delays in the project completion. They found that, due to the uncertainty in the activity completion time, critical tasks are not necessarily those belonging to the critical path.

Proposed a PERT-based MILP model that supports time-related project risk management and which, in turn, helps discern between risks those have to be accepted \& risks those can be removed in some way, ensuring that client requirements are satisfied with respect to project completion time at minimal cost.

This paper provides a methodology to measure the risk interdependence; based on the analysis of the risk interdependence, they constructed a model for selecting risk response strategies taking into consideration the expected risk loss \& risk interdependence. Investigates the effect of dynamic risk interactions on schedule delay in infrastructure projects, a system dynamics model was developed to investigate risk effects on a project schedule which was based on the causal loops and the underlying relations among the variables.

Proposed a fuzzy-based risk assessment model that calculates the likelihood of occurrence, magnitude of impact, and risk criticality of a set of risk factors, in order to determine the most critical ones with respect to the project's success.

It proposed a multi objective mixed integer linear programming to minimize "project total extra cost", "project total risk enhancement" and "project total quality reduction" subject to time constraint. 
Table 3 continued

$\begin{aligned} & \text { Contribution/Focus } \\ & \text { Weference }\end{aligned}$
$\begin{array}{r}\text { In this paper, three factors were identified, namely, price escalation of raw material, delay in } \\ \text { planned activity, and lack of co-ordination between construction parties, those lead to } \\ \text { significant cost overuns. For this purpose survey was carried out and data was analyzed } \\ \text { using various statistical tools in SPSS. }\end{array}$
$\begin{array}{r}\text { Addressed risk assessment \& management, proposing a technique for risk prevention and } \\ \text { balancing. The technique determines the risk degree of a project through the monitoring } \\ \text { of the actual performances of a set of input factors, and the application of WSM for the } \\ \text { quantification of the risk degree. }\end{array}$
$\begin{array}{r}\text { A review of fuzzy and hybrid methods those are being used in construction risk management } \\ \text { research is presented. Authors observed a frequent use of fuzzy analytical network } \\ \text { process, however limited by its lengthy calculations, is now being replaced by fuzzy } \\ \text { Bayesian belief network for risk assessment. }\end{array}$
$\begin{array}{r}\text { This paper analyzed thousands of risk data points and claims that risk identification is } \\ \text { significantly correlated to risk assessment and mitigation, however, same is not true with } \\ \text { risk assessment and mitigation. }\end{array}$
$\begin{array}{r}\text { Assessing risks by risk-scores can be problematic, because may a times marginalized groups } \\ \text { of risks turn out to be significant. Authors' proposed a robust scoring system which could } \\ \text { ensure that allocated risk factors are neither too high nor too low. }\end{array}$

ensure that allocated risk factors are neither too high nor too low.

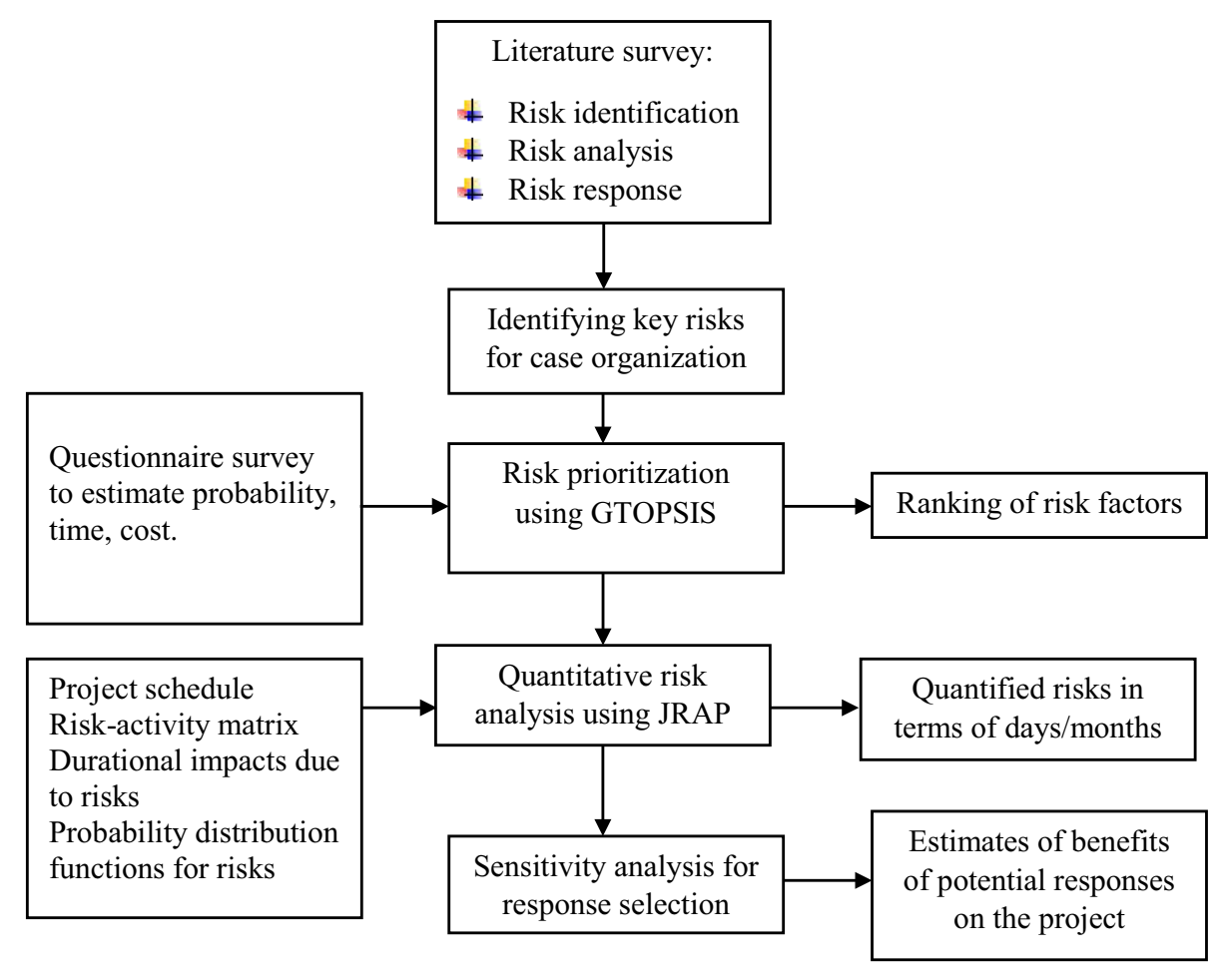

Figure 1. Research methodology.

better risk treatment strategy [18]. Fang et al proposed a quantitative framework of analysis for supporting decision making in project risk response planning by using Genetic Algorithm [19]. Our paper is in line with these recent developments in the field of project risk analysis and response selection. We link the risk factors to specific activities of the project network, and thus the impact of individual risks on the network topology is determined.

The state-of-the-art in the domain of risk quantification and selection of risk response strategy was revealed primarily to be exploratory, and research has mainly focused on the development of conceptual frameworks. The efforts 
are limited in terms of the development of quantitative risk assessment and risk response strategy framework. The major problem in the quantification of risk and developing risk response strategy is the intangibility associated with some of the risks and individual subjective preferences in choosing risk response strategy. To deal with the aforementioned issue, this research proposes a novel methodology that integrates Group Technique for Order Preference by Similarity to Ideal Solution (GTOPSIS), Judgemental Risk Analysis Process (JRAP), and Monte-Carlo Simulation, that takes into account project schedule as well, while computing cost and time escalations linked to various risks.

\section{Research methodology}

There are many qualitative and quantitative risk analysis processes available to us, but none considers project schedule/ network which is a vital element of any project. It should be noted that a risk does not affect a project if the activity it is falling upon is having enough slack associated with it. In view of this, an integrated approach (as shown in figure 1) is proposed for managing risks in an infrastructure project. At first, risks were prioritised using GTOPSIS. The output from GTOPSIS is used as input to JRAP and MCS. Risks with a lower ranking in GTOPSIS could be eliminated from further analysis. JRAP along with MCS helps calculate probabilistic project duration. To quantify risks (in days), JRAP and MCS along with Sensitivity Analysis are used.

\subsection{GTOPSIS methodology}

Out of a number of methods used in Multi-Criteria Decision Making (MCDM) like AHP, ANP, ELECTRE, PROMETHE, TOPSIS, etc., one of the methods that can be more suitable for the risk prioritisation, when there are a large number of risk factors is TOPSIS. The literature reports various applications of TOPSIS in a project environment. For example, Taylan et al [20] had demonstrated an application of Fuzzy TOPSIS and Fuzzy AHP for the risk assessment in construction projects. Chang [21] proposed a decision model based on a combination of fuzzy AHP and TOPSIS to manage uncertainty and imprecision of green building project evaluation during the structure process. Vinodh and Swarnakar [22] have proposed a hybrid approach based on fuzzy DEMATEL-ANP-TOPSIS for lean six sigma projects selection for an automotive component manufacturing organisation.

GTOPSIS is a modification of TOPSIS where decision makers are more than one. It is important to have a number of decision makers and to carry out group decision making because estimates provided by experts for risk analysis tends to bring in the bias they already have (towards certain risk factors). Bringing in group decision subdues this effect while carrying out risk analysis. Finally, TOPSIS is highly efficient and suitable for cases where a large number of attributes and alternatives are present and handy for both subjective and objective data availability [23]. Although other tools and technique like Fuzzy TOPSIS could also be used at this stage of risk analysis, however, we decided to go with GTOPSIS. The steps of GTOPSIS are listed as below.

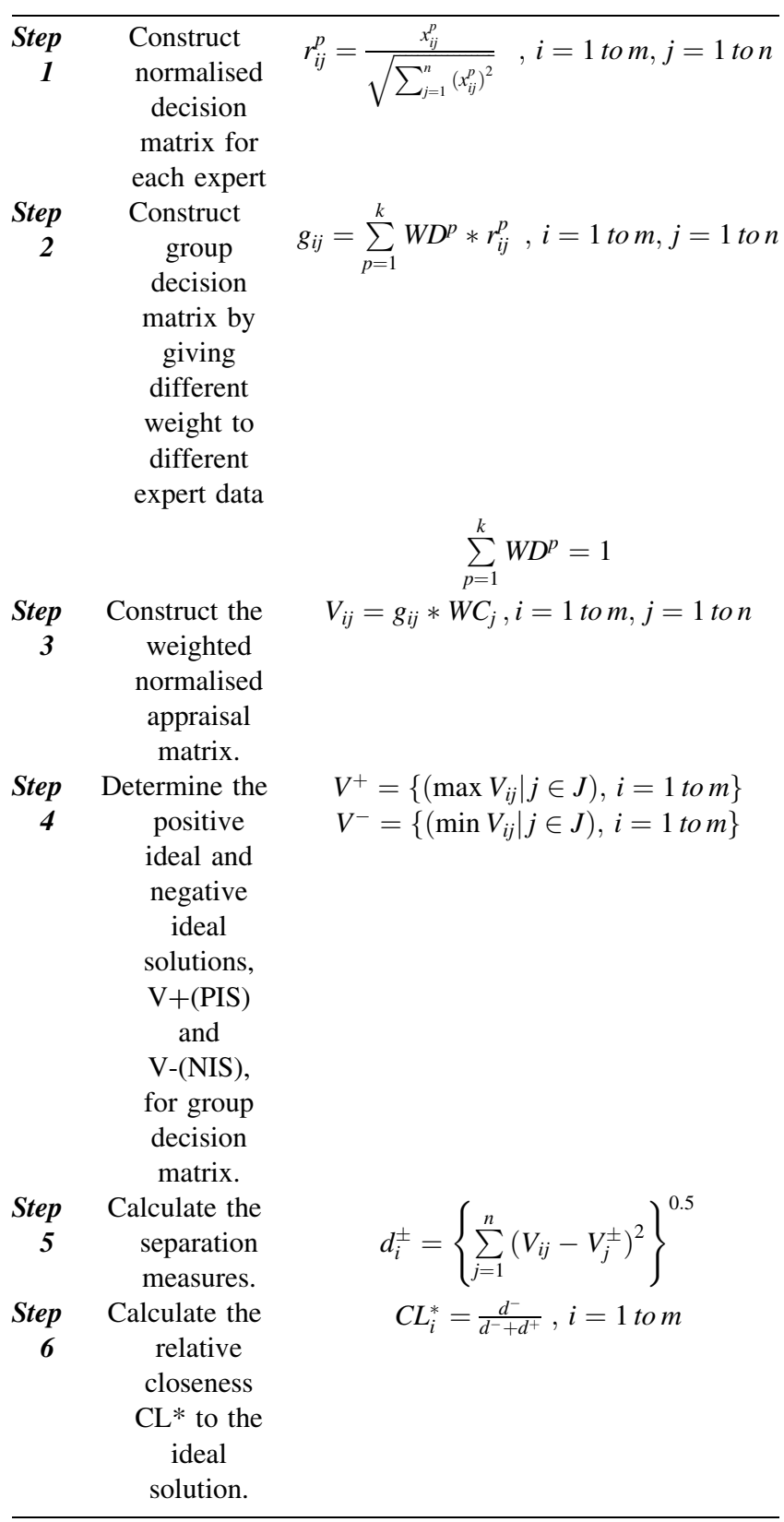

\subsection{JRAP methodology}

The method is called as Judgemental risk analysis process which was developed by [24]. The method involves a number of managerial steps and an equation that offers the variation in each activity's duration in the schedule. The features of JRAP make this methodology useful in uncertain conditions of which there are limited historical data. 
This increases its suitability for converting a high level of uncertainty to risk judgementally [25]. Given that every construction project has a unique characteristic (that vary according to the construction type, execution time and its environment) that differentiates it from even a similar projects; the methodology has an advantage over the other methods while carrying out risk analysis. The steps involved in JRAP are listed as below.

\begin{tabular}{cc}
\hline $\begin{array}{c}\text { Step 1: Model } \\
\text { deterministic }\end{array}$ & $\begin{array}{c}\text { Deterministic time schedule plan is basically } \\
\text { 'project schedule' available with the planners } \\
\text { time schedule } \\
\text { plan of the }\end{array}$ \\
project & durations and all the dependencies of \\
& different activities. The need for the \\
deterministic model arises from its power of \\
highlighting the potential project risks.
\end{tabular}

Step 2: Identify, To carry out risk identification, any of the risk classify and identification methods can be employed determine namely brainstorming, checklist, literature critical risks survey. Further to determine critical risks any of the risk prioritising tools like probability impact matrix, risk probability and impact assessment, decision tree and MCDM tools like AHP, TOPSIS can be employed depending on the availability of data.

Step 3: Assign probability distributions:

Step 4: Establishing activity-risk factor matrix and modelling.
This step of JRAP is to assign probability distributions to the identified risks in the previous step. This can be done by using experience and engineering judgement in case there is no historical data to conduct a detailed statistical analysis. Common distributions like beta, triangle, exponential, lognormal, etc. can be used for representing the critical risks. Note: the type of distribution can vary from one activity to another activity.

The activity-risk factor matrix can be established using a combination of historical data and expert's judgement. For every activity, a subset of the set of all the risks is identified.

According to JRAP: Duration of activity = Minimum Activity Time + Risk

Factor Affects, where risk factor affect is the effective sum of all risks for given activity. Risk factor effect $=[$ Maximum activity time - Minimum activity time $]^{*}$ Percentage affect $*$ Degree of materialisation; percentage affect suggests what the loss may be if the given risk materialises to $100 \%$, maximum activity time can be considered as pessimistic time as known in PERT analysis. The degree of materialisation basically is random numbers for each delay factor which are generated from a particular representative distribution. The random values are generated between minimum and maximum $(0,1)$ using the Monte-Carlo simulation technique using risk distribution assigned in step 3. Accordingly:

Duration of activity = Minimum activity time $+[$ Maximum activity time - Minimum activity time]

$\left[\left(P A_{1} *\right.\right.$ Random $\left._{1}\right)+\left(P A_{2} *\right.$ Random $\left._{2}\right)+\left(P A_{3}\right.$ $*$ Random $\left._{3}\right)+\cdots+\left(P A_{n} *\right.$ Random $\left.\left._{n}\right)\right]$

Step 5: Model stochastic time schedule plan of the project and Run MonteCarlo Simulation
MCS uses the activity-risk factor matrix in order to calculate the variation in activity durations. Because the duration of every activity changes stochastically according to the PDF given to it, the critical path can be different for every simulation runs. A minimum of 1000 runs can be performed to get probabilistic project durations.

Since JRAP uses judgemental way to determine PDFs, Roger and Petch [26] provides few guidelines for the selection of PDFs. This includes:

a) Is it a discrete variable? if yes, try Poisson, or Binomial (if modelling an 'either/or' variable);

b) Is it symmetric and bounded variable? if yes, use the triangular distribution;

c) Is it asymmetric and bounded variable? if yes, use the triangular; and if you have no idea about the shape, use a uniform distribution;

d) Is it an asymmetric and bounded at one end but unbounded at another end variable? if yes, use exponential or lognormal distribution.

Apart from this, Dawood [24] recommends various PDFs for different types of risks (as listed in table 4).

The fifth step in JRAP makes use of Monte- Carlo simulation (MCS) will be used. There are select softwares like crystal-ball, @ risk and other MS-Excel extensions which can perform MCS. In our analysis @ @isk (version 6.0) is used. According to McKenna [27], the steps of MonteCarlo Simulation are listed as below.

\begin{tabular}{|c|c|}
\hline $\begin{array}{l}\text { Step 1: Define domain of } \\
\text { possible inputs }\end{array}$ & $\begin{array}{l}\text { Identify the probabilistic } \\
\text { element and find the } \\
\text { probability distribution for } \\
\text { each. The probability } \\
\text { distribution of a random } \\
\text { variable } X \text { is a description of } \\
\text { the probabilities associated } \\
\text { with the possible values of } X\end{array}$ \\
\hline $\begin{array}{l}\text { Step 2: Generate inputs } \\
\text { randomly from probability } \\
\text { distribution function }\end{array}$ & $\begin{array}{c}\text { Generate a random number from } \\
0 \text { to } 1 \text { (using methods like a } \\
\text { linear congruential generator, } \\
\text { multiple recursive generators, } \\
\text { jumping ahead method and } \\
\text { use that to generate random } \\
\text { variate (using methods like } \\
\text { inverse transformation } \\
\text { method, acceptance-rejection } \\
\text { method, composite method, } \\
\text { etc. to each event } \\
\text { corresponding to its }\end{array}$ \\
\hline
\end{tabular}


Step 3: Perform a deterministic computation using the inputs

Step 4: Do the iteration and aggregate the results cumulative probability distribution.

Use the number generated to represent the occurrence of the random event end perform one of the deterministic calculations using those numbers.

Repeat step 2 and 3 until a desired number of runs are over. The results obtained in every iteration must be recorded, and results must be aggregated.

\section{Data collection and case study}

The data collection was done through interviews and reviews from an ongoing industrial project located in Bangalore. The information gathered was repeatedly discussed with the senior managers and necessary modifications were applied through triangulation. The results were discussed with the senior managers, and subsequent modifications are accepted.

The prime contractor in the project is Shimizu Corporation India Pvt. Ltd. With more than 200-year history, it is a Multi-National organisation which believes in its people, keeps the environment in the priority list, believes in keeping good relationships with government and society whereever it is operating; it has shown good compliance with local laws and regulations. Shimizu Corporation India Ltd. is a branch of Shimizu Corporation (bases in Japan) which is the leading engineering, architectural and construction firm, offering an integrated, comprehensive design, planning and build solutions for a broad range of engineering and construction projects around the world. It has been recognised as one of the top 20 contractors in the world and top 5 in Japan.

It had a construction project for an industrial facility which will manufacture Honda products. The total duration

of the project was approximately 2 years which started in August 2011. The total planned cost of the project was Rs 350 crore. Although the main contractor has more than 20 years of experience of operations in India, the subcontractors employed by it in the project has a varying degree of experience. The most experienced subcontractor employed in the project was Simplex Infrastructure Limited. The main contractor is financially very strong and can carry forward the project without any hurdles.

The project is being carried out in industrial zone developed by the state government, so, there were no problems while land acquisitions. Although the availability of labour is not very high in the location and most of the labours are local farmers. During farming seasons the organisation faces a shortage of labour.

The necessary data were collected from the following reports of Shimizu Corporation India Pvt Ltd.

- Master program for execution.

- Weekly progress reports of power facility and utility area.

- Productivity reports productivity improvement suggestions.

A detailed review of the literature has helped to identify the 19 most appropriate and relevant risks (table 5) those may occur in a construction project. We considered those 19 factors for the purpose of further analysis. However, risk factors can vary from region to region and project to project. Ling and Hoi [28] have categorised a number of risk factors pertaining to the Indian context, which include risk categories like managerial risks, design risks, constructionrelated risks, regulatory and political risks.

To carry out qualitative risk analysis three criteria were selected namely, a) probability of occurrence, b) impact on duration and c) impact on cost. Participants were asked to provide estimates for these criteria with respect to various risks cited in table 5 .

The survey was conducted via e-mail and about 100 professionals, who are having experience in carrying out similar projects, were contacted. Also, a brief introduction

Table 4. Risk types and recommended PDFs [24].

Recommended

Type of risk

Application

PDF

Weather condition, labor productivity, Where the outcome is between two extremes and the tendency is towards materials delay, soil conditions.

Weather, subcontractors default one outcome

Where there is a range between which the outcomes are equally likely, and the probability of an outcome beyond that range decreases the further away from it, towards the extreme outcome Where there is a risk an event can occur

Triangle

Trapezium

Equipment failure

Design changes and incomplete design scope

Unavailability of materials, equipment and labor, Delay in approvals

Where the outcome is likely for narrow range towards zero and has no limit at other end

Binomial

Rectangle

Lognormal 
Table 5. Key risk factors in construction project.

\begin{tabular}{lc}
\hline Risk category & Risk factor \\
\hline Construction/subcontractor risks & Low productivity of man/machine [53] \\
Defective construction [54] & Unavailability of man/machine/ material [55] \\
& Poor coordination among subcontractor [53] \\
Conflict with subcontractor [56] & Bureaucracy and sluggish governmental process [3] \\
Financial /political/economic risk & Financial instability of sub-contractor [54] \\
& Inadequate cost estimations [54] \\
Design related risks & Inflation of construction material/labor cost [54] \\
& Prosecution by third party [3] \\
& Design change request by client [28] \\
Defective design by designer [3] \\
Inadequate site information [3] \\
Poor communication of design [3] \\
Management risks & Poor understanding of rules and regulations [28] \\
& Late delivery of machine/material at construction site [54] \\
& Unsuitable weather conditions [55] \\
Labor disputes and strikes [56] & Accidents at site [28]
\end{tabular}

to the project was given to them. About 43 responses were collected out of which 2 were rejected for analysis because those were not completely filled. All the responders were having experience of 1 year to 10 years. Table 6 shows the demography of the responders.

The data thus collected was used for prioritisation of risks using GTOPSIS. Other information that is required to carry out the analysis is the weights given to each criterion. This demands consideration of three criteria: the probability of occurrence, impact on cost and impact on time. Based on an expert opinion (weights are given to the level of experience as shown in table 6) and recommendation provided by Mojtahedi et al [29], the criteria are assigned weights as $0.4,0.3,0.3$. Once risks are prioritized, the next step is to collect data for JRAP. The data that is required for further analysis are:
i. Project schedule and all the dependencies.
ii. Probability distribution functions for all risk factors.
iii. Impact on duration in a percentage of activity duration.
iv. Activity risk matrix.

The project schedule was provided by Shimizu Corporation India Pvt. Ltd as a master program, all the dependencies among activities were also provided in the same. This data was then converted to MS- Project format. The risk factors which were prioritised using GTOPSIS, the next step was to identify PDFs for them. This was done by literature survey [24, 25]. Table 7 shows the PDFs for the degree of materialisation assigned to various risks.
Table 6. Demography of the responders and given weightages.

\begin{tabular}{lcc}
\hline $\begin{array}{l}\text { Responder } \\
\text { Experience }\end{array}$ & $\begin{array}{c}\text { Number Of } \\
\text { Responses }\end{array}$ & $\begin{array}{c}\text { Weightage } \\
\text { Given }\end{array}$ \\
\hline 1-3 Years & 24 & 1 \\
3-6 Years & 14 & 2 \\
6-10 Years & 3 & 3 \\
\hline
\end{tabular}

To quantify the impact on duration (in the percentage of activity durations), the data collected for previous analysis was utilised. The weighted mean of impact on duration of the all the responses collected from 41 responders was used for the purpose. The values are given in table 7. Similarly, activity risk matrix was derived using data collected through a literature survey and using general reasoning. Finally, an activity risk matrix is developed using a reasoning approach (table 7) validated by literature [24, 25, 30-32].

\section{Results and discussion}

The analysis was carried out using Excel spreadsheet. Table 8 shows the result of qualitative risk analysis (GTOPSIS). The risk factors with a higher value of $\mathrm{C}^{*}$ are important risks and must be taken care with priority. It should be noted that risk factors having $\mathrm{C}^{*}$ value lower than 0.2 (highlighted in green) were neglected for further analysis in JRAP. 
Table 7. PDFs of risk factors and weighted impact on activity durations.

\begin{tabular}{|c|c|c|c|c|}
\hline $\begin{array}{l}\text { S } \\
\text { No. }\end{array}$ & Risk factor & $\begin{array}{c}\text { Characteristic of activity (Reasoning to develop } \\
\text { activity risk matrix) }\end{array}$ & $\begin{array}{l}\text { PDFs for degree } \\
\text { of } \\
\text { materialization }\end{array}$ & $\begin{array}{l}\text { Weighted mean durational } \\
\text { impact in percent of activity } \\
\text { durations }\end{array}$ \\
\hline 1 & $\begin{array}{l}\text { Bureaucracy and } \\
\text { sluggish governmental } \\
\text { process }\end{array}$ & Activities which require governmental approvals & $\begin{array}{l}\text { Lognorm } \\
(0.44,0.2)\end{array}$ & 0.24 \\
\hline 2 & $\begin{array}{l}\text { Low productivity of } \\
\text { man/machine }\end{array}$ & $\begin{array}{c}\text { Almost all activities which involves human or old } \\
\text { machines }\end{array}$ & Triang $(0,0,1)$ & 0.24 \\
\hline 3 & $\begin{array}{l}\text { Late delivery of } \\
\text { machine/material at } \\
\text { construction site }\end{array}$ & $\begin{array}{c}\text { Activities which require special parts/material } \\
\text { which is not available locally }\end{array}$ & Triang $(0,0.6,1)$ & 0.23 \\
\hline 4 & Defective construction & Activities in which highly skilled labor is required. & $\begin{array}{l}\text { Triang } \\
(0,0.38,1)\end{array}$ & 0.21 \\
\hline 5 & $\begin{array}{l}\text { Unavailability of } \\
\text { man/machine/ } \\
\text { material }\end{array}$ & $\begin{array}{c}\text { During farming reason man /machine will not be } \\
\text { abundant, although skilled technicians will } \\
\text { remain available }\end{array}$ & Triang $(0,0.7,1)$ & 0.16 \\
\hline 6 & $\begin{array}{c}\text { Poor coordination among } \\
\text { subcontractor }\end{array}$ & $\begin{array}{l}\text { At locations where many sub-contractors engaged } \\
\text { at the same time }\end{array}$ & Triang $(0,0.2,1)$ & 0.12 \\
\hline 7 & $\begin{array}{c}\text { Financial instability of } \\
\text { subcontractors }\end{array}$ & $\begin{array}{l}\text { During latter period of the project, in activities } \\
\text { which involves civil contractors }\end{array}$ & Triang $(0,0.2,1)$ & 0.2 \\
\hline 8 & $\begin{array}{l}\text { Conflict with } \\
\text { subcontractor }\end{array}$ & $\begin{array}{l}\text { Previous disputes impact the start of the activity, } \\
\text { (sub-contractors want their disputes to be } \\
\text { resolved first) }\end{array}$ & Triang $(0,0.3,1)$ & 0.08 \\
\hline 9 & $\begin{array}{c}\text { Design/scope change } \\
\text { request }\end{array}$ & $\begin{array}{c}\text { Design change can only requested in design } \\
\text { approval stage }\end{array}$ & Uniform $(0,1)$ & 0.21 \\
\hline 10 & $\begin{array}{c}\text { Defective design by } \\
\text { designer }\end{array}$ & $\begin{array}{c}\text { Delays the design stage, or, during construction } \\
\text { stage }\end{array}$ & Triang $(0,0.4,1)$ & 0.14 \\
\hline 11 & $\begin{array}{c}\text { Inadequate site } \\
\text { information }\end{array}$ & During works like, excavation or land development & Triang $(0,0.7,1)$ & 0.15 \\
\hline 12 & $\begin{array}{l}\text { Poor communication of } \\
\text { design with } \\
\text { construction team }\end{array}$ & Activities which contains complex design element. & Triang $(0,0.3,1)$ & 0.14 \\
\hline 13 & $\begin{array}{l}\text { Unsuitable weather } \\
\text { conditions }\end{array}$ & Activities which falls on rainy reasons & Triang $(0,0.8,1)$ & 0.12 \\
\hline
\end{tabular}

Out of all the risks, top 13 risks were selected for further analysis, rest all were eliminated either because they were very insignificant or were purely cost related and had little effect on project schedule or it was not possible to assign their impacts on individual activities. Data collected for the case organisation can be used for Judgemental risk analysis. Following is an example of how to calculate activity duration using MCS in JRAP. Following computation shows iterations of MCS for activity "detailed design".

The equation used for the purpose is

$$
\begin{aligned}
& \text { Activity duration }=\text { Minimum activity duration } \\
& \text { + Minimum activity duration } \\
& {\left[\left(\text { Random }_{1} * \text { Percentage } \text { Impact }_{\text {risk } 1}\right)\right.} \\
& +\left(\text { Random }_{2} * \text { Percentage Impact } \text { risk }\right) \\
& \text {......... } \left.\left(\text { Random }_{n} * \text { Percentage Impact }_{\text {risk-n }}\right)\right]
\end{aligned}
$$

Sample calculations to find an activity duration is shown below:
Iteration 1. Activity duration $=69+69$ $(1 * 0.24+1 * 0.21+1 * 0.14)=109$ days.

Iteration 2. Activity duration $=69+69$ $(0.5 * 0.24+0.5 * 0.21+0 * 0.14)=84.5$ days.

Iteration 3. Activity duration $=69+69$ $(0.3 * 0.24+0 * 0.21+0.3 * 0.14)=76.8$ days.

Iteration 4. Activity duration $=69+69$ $(0 * 0.24+0.3 * 0.21+0.5 * 0.14)=78$ days.

To carry out the complete analysis Excel spreadsheet was prepared. The Excel extension @Risk (version 6.0) was used for MCS. MS-Project activities and dependencies were imported into the MS-Excel sheet. All the data were fed into the software, and the MCS was carried out for 1000 iterations. On every iteration, durations for 117 activities were calculated and the deterministic value thus calculated is fed into the project schedule to determine project completion date. This was done for 1000 times, and project completion dates were recorded for every run. @RISK, the simulation software that was used in our study, is equipped with a convergence monitor that calculates the change in 
Table 8. Results of GTOPSIS (risk factor's relative distance from ideal).

\begin{tabular}{lcc}
\hline Sl. No. & Risk factors & C* (relative distance from ideal) \\
\hline 1 & Defective design by designer & 0.500159 \\
2 & Low productivity of man/machine & 0.939874 \\
3 & Bureaucracy and sluggish governmental process & 0.845543 \\
4 & Design change request by client & 0.832023 \\
5 & Late delivery of machine/material at construction site & 0.686344 \\
6 & Defective construction & 0.620842 \\
7 & Poor coordination among subcontractor & 0.485721 \\
8 & Unavailability of man/machine/ material & 0.460366 \\
9 & Inadequate cost estimations & 0.453788 \\
10 & Poor communication of design with construction team & 0.409889 \\
11 & Financial instability of sub-contractor & 0.34469 \\
12 & Inflation of construction material/labor cost & 0.339872 \\
13 & Inadequate site information & 0.336999 \\
14 & Conflict with subcontractor & 0.299334 \\
15 & Unsuitable weather conditions & 0.20634 \\
16 & Prosecution by third party & 0.172655 \\
17 & Labor disputes and strikes & 0.162931 \\
18 & Poor understanding of rules and regulations & 0.141062 \\
19 & Accidents at site & 0.095415 \\
\hline
\end{tabular}

Table 9. Results of MCS with JRAP.

\begin{tabular}{|c|c|c|c|c|}
\hline Sl.No. & Risks included in calculation & $\begin{array}{l}\text { Project Completion Date } \\
\text { (Mean) }\end{array}$ & $\begin{array}{l}\text { Standard Deviation } \\
\text { (days) }\end{array}$ & $\begin{array}{c}\text { Project Completion Date (95\% } \\
\text { Confidence) }\end{array}$ \\
\hline 1 & All & $06^{\text {th }}$ Jan 2014 & 16 & $4^{\text {th }}$ Feb 2014 \\
\hline 2 & $\begin{array}{l}\text { All except low productivity from } \\
\text { man/machine }\end{array}$ & 25-Nov-13 & 11 & 17-Dec-2013 \\
\hline 3 & All except risk of defective construction & 6-Dec-13 & 14 & 31-Dec-2013 \\
\hline 4 & All except risk of financial instability & 10-Dec-13 & 15 & 2-Jan-2014 \\
\hline 5 & $\begin{array}{c}\text { All except sluggish governmental process/ } \\
\text { approvals }\end{array}$ & 10-Dec-13 & 15 & 2-Jan-2014 \\
\hline 6 & All except unsuitable weather conditions & 25-Dec-13 & 17 & 20-Jan-2014 \\
\hline 7 & $\begin{array}{l}\text { All except poor communication with design } \\
\text { team }\end{array}$ & 24-Dec-13 & 15 & 20-Jan-2014 \\
\hline 8 & All except disputes with subcontractors & 30-Dec-13 & 16 & 23-Jan-2014 \\
\hline 9 & $\begin{array}{l}\text { All except poor coordination among } \\
\text { teams/subcontractors }\end{array}$ & 25-Dec-13 & 16 & 23-Jan-2014 \\
\hline 10 & $\begin{array}{c}\text { All except late delivery of } \\
\text { machine/material }\end{array}$ & 25-Dec-13 & 15 & 24-Jan-2014 \\
\hline 11 & All except defective design & 27-Dec-13 & 16 & 27-Jan-2014 \\
\hline 12 & $\begin{array}{c}\text { All except risk of inadequate site } \\
\text { information }\end{array}$ & 1-Jan-14 & 17 & 27-Jan-2014 \\
\hline 13 & All except unavailability of labor/machine & 1-Jan-14 & 17 & 29-Jan-2014 \\
\hline 14 & $\begin{array}{c}\text { All except risk of design/scope change } \\
\text { request }\end{array}$ & 6-Jan-14 & 15 & 30-Jan-2014 \\
\hline
\end{tabular}

mean and standard deviation at every 100 iterations. In our case, no significant change in mean and standard deviation was observed well before 1000 iterations, but to be on safer side, we decided to go for 1000 iterations.

The results of JRAP and MCS, with all risks active are presented in table 9, Sl.No. 1. It should be noted that scheduled project completion time was August 2013, but according to our approach, it was predicted that the project duration will be escalated till the end of January 2014, with 95\% confidence.

Next step is to quantify individual risks in durational terms. By eliminating a risk completely from the project by assigning a degree of materialisation to a value closer to zero and then running MCS for another 1000 iterations 
Table 10. Ranking of risks using GTOPSIS and JRAP.

\begin{tabular}{lcc}
\hline Rank & GTOPSIS $\left(\mathrm{C}^{*}\right)$ & JRAP (Delay due to, in Days) \\
\hline 1 & Low productivity of man/machine $(0.93)$ & Low productivity from man/machine (49 days) \\
2 & Sluggish governmental process/approvals $(0.84)$ & Risk of defective construction $(35$ days) \\
3 & Design change request by client $(0.83)$ & Risk of financial instability (33 days) \\
4 & Late delivery of machine/material $(0.68)$ & Sluggish governmental process/approvals $(33$ days) \\
5 & Defective construction $(0.62)$ & Unsuitable weather conditions $(15$ days) \\
6 & Defective design by designer $(0.5)$ & Poor communication with design team $(15$ days) \\
7 & Poor coordination among subcontractor $(0.48)$ & Disputes with subcontractors $(12$ days) \\
8 & Unavailability of man/machine/ material $(0.46)$ & Poor coordination among subcontractors $(12$ days) \\
9 & Poor communication with design team $(0.4)$ & Late delivery of machine/material $(11$ days) \\
10 & Financial instability of sub-contractor $(0.34)$ & Defective design $(8$ days) \\
11 & Inadequate site information $(0.33)$ & Risk of inadequate site information $(8$ days) \\
12 & Conflict with subcontractor $(.29)$ & Unavailability of labor/machine $(6$ days) \\
13 & Unsuitable weather conditions $(0.21)$ & Risk of design/scope change request $(5$ days) \\
\hline
\end{tabular}

Table 11. Variations introduced to design related risks.

Risk Intensity

gives us new probabilistic project duration. Now by comparing the results with the probabilistic project duration when all risks were active, we get the share of the given risk. An analogy can be drawn from Morse test for multicylinder internal combustion engine.

$$
\begin{gathered}
\text { Impact }_{\text {risk(n) }}=\text { Project Duration }_{\text {all risks active }} \\
- \text { Project Duration }_{\text {without risk(n) }}
\end{gathered}
$$

Table 9 also shows the result when risks were eliminated one at a time. It has been revealed that productivity related risks were most important among all other risk factors. It can be inferred that by eliminating low productivity one can effectively decrease the probable delay in project completion by 49 days. For the case project, it is recommendable to have a close look at the productivity of the labours on a daily basis. Also the causes that may lead to low productivity must be eliminated from the project, or else the number of labour must be increased (which will lead to increase in cost).
In the presence of cost related data, a similar analysis could be done for project's cost, and so the probabilistic project costs could be determined which can help estimate contingency amounts. There will be cost escalations depending on the nature of the risks, also, the delay in project completion will lead to cost escalations of at least equal to the sum of inflation, overhead cost, and additional interest cost for the period [2].

Table 10 shows the ranking of risks, as done by GTOPSIS and JRAP. In both the analysis there is a huge difference between risk rankings. This can be attributed to the fact that in JRAP stochastic nature of risks, activities and project duration is also considered, while qualitative risk analysis does not consider project schedule/network which is a vital element of any project. A risk do not affect a project if the activities it is associated with is having enough slack available with it.

For the case study "Design change request by client" was the third most important risk, when the risk analysis was carried out using GTOPSIS while the same risk is 
Table 12. Variations introduced to sub-contractors related risks.

Low productivity of man/machine

Table 13. Results of Sensitivity analysis as a result of potential mitigation measures.

\begin{tabular}{|c|c|c|c|c|}
\hline S1.No. & Project Duration & $\begin{array}{l}\text { Project Completion Date } \\
\text { (Mean) }\end{array}$ & $\begin{array}{l}\text { Standard Deviation } \\
\text { (days) }\end{array}$ & $\begin{array}{c}\text { Project Completion Date (95\% } \\
\text { Confidence) }\end{array}$ \\
\hline 1 & When no risks were mitigated & $06^{\text {th }}$ Jan 2014 & 16 & $4^{\text {th }}$ Feb 2014 \\
\hline 2 & $\begin{array}{c}\text { When design related risks were } \\
\text { mitigated }\end{array}$ & 15-Dec-13 & 15 & 13-Jan-2014 \\
\hline 3 & $\begin{array}{l}\text { When sub-contractor related risks were } \\
\text { mitigated }\end{array}$ & 10-Oct-13 & 6 & 22-Oct-2013 \\
\hline
\end{tabular}

ranked last when risk analysis is done using JRAP. When we looked into the project schedule what was found was, the activities which were prone to this risk were having huge slack associated with them, so even if there is a delay in completion of an activity due to given risk the project will have enough slack to continue without much loss caused due to that particular risk.

\subsection{Response selection and sensitivity analysis}

A risk cannot be eliminated completely, however, adopting preventive measures are likely to reduce materialisation of a risk. In this regard we find sensitivity analysis to be a useful tool in decision making. Sensitivity analysis also referred to as what-if or simulation analysis is a way to predict the outcome of a decision given in a certain range of variables.

By using sensitivity analysis, various response could be analyzed further and its effect on the project could be assessed. In JRAP, two parameters those could be varied are namely, a) degree of materialisation and b) impact on duration. Dawood [24] in his paper suggested if activities in the rainy season can be shifted to summer, the mean of probability distribution for risk on weather conditions can be shifted towards zero, judgementally. Similarly, the impact on activity duration due to bad weather will also be reduced in the summer season. By following the same concept, two response could be assumed, a) employing an expert design team, b) employing experienced subcontractors.

By employing an expert design team, we will see a decrease in the degree of materialisation and impact in risk factors namely, a) defective design by designer, b) poor communication of design with construction team and c) design/scope change request. Table 11 shows the variation that was introduced into these risk factors. Table 13 (S1.No. 2) shows probabilistic project duration as a result of potentially employing expert design team.

By comparing the results with the originally calculated project duration, it could be found that there is a decrease in probabilistic project duration by 20 days ( $95 \%$ confidence). This gives a better understanding of what might happen when an expert design team is employed. It helps in decidingpon the affordability of the given response. 
Similarly, by employing experienced sub-contractors, a decrease in the degree of materialisation and impact in risk factors will be observed, namely a) low productivity of man/machine, b) poor coordination among subcontractor, c) conflict with subcontractor and d) defective construction. Table 12 shows the variations that were introduced into these risk factors. Table 13, S1.No. 3 shows probabilistic project duration as a result of potentially employing experienced subcontractors.

By comparing the results with the originally calculated project duration, we find that there is a decrease in probabilistic project duration by 3 months ( $95 \%$ confidence). This gives a better understanding of what might happen when experienced sub-contractors are employed, this can help us decide on the affordability of the given response.

\section{Conclusion}

Our present analysis is limited to quantification of risks in terms of time escalations pertaining to individual risk factors, also, how finally sensitivity analysis could be employed to analyse various response is demonstrated. There could be a number of risk mitigation strategies which could be devised by a project manager. In this article, we demonstrated few strategies those could be employed for risks like low productivity, poor coordination, defective design, etc. which is presented in the results and discussion section, and the sensitivity analysis section. It should be noted that any of the decisionmaking tool, say for example decision tree, could be used if cost and benefits of various response alternatives are known; this is exactly where the proposed methodology comes into picture. The proposed methodology could help calculate the reduction in cost and time escalation of the project, achieved as a result of implementation of a particular response. This accommodates the uncertainty involved in activity durations which is there because of the presence of risks itself. The risks perceived as very severe may not be that severe if activities of the project are having enough slack.

Finally, advantages provide by the proposed methodology are: a) the methodology helps to forecast the probability distribution function of project duration; b) helps identify schedule-related risks involved in the early stages of the project; c) helps quantify risks in units of time and potentially cost; d) provides better risk priority as it considers slack associated with the activity; e) helps to evaluate various responses using sensitivity analysis. It enables an efficient use of resources by relating the relative impact of risks on schedule and cost overrun. Such knowledge would improve project planning and coordination among various stakeholders as the project would not pursue the risk factors equally. Further, a stochastic consideration of risk factors facilitates the decision making under a dynamic environment.

\section{Scope for future work}

Some of the limitations of the proposed approach is highlighted as follows.

- A fuzzy approach to this problem could be a nice extension of the present work. This would require a combination of Fuzzy GTOPSIS and Fuzzy JRAP methods [33].

- At present, it is not possible to get exact data in terms of percentage escalation in cost and time of each and every activity and associated risks. A rigorous data collection campaign has to be undertaken to overcome this limitation in the Indian context.

- The above methodology does not consider correlation among various risk factors. These limitations could be eliminated in future studies.

There is a need to correlate various risk factors while carrying out Monte-Carlo simulation. Correlation between various risk factors must be studied and must be employed in probability distribution functions for the degree of materialisation. The results of the proposed method can be compared with the method like Bayesian belief networks, as BBN focuses on a similar problem [34]. We also propose the use of machine learning and artificial intelligence techniques in the field of construction and risk management.

\section{Reference}

[1] Kalady R 2012 Project management in infrastructure. Construct. Architect. Mag. 20-26

[2] Ahuja H N and Nandakumar V 1985 Simulation model to forecast project completion time. J. Construct. Eng. Manag. 111(4): 325-342

[3] Zou P X W, Zhang G and Wang J 2007 Understanding the key risks in construction projects in China. Int. J. Proj. Manag. 25: 601-614

[4] PMI 2008 A guide to the project management body of knowledge (PMBOK guide). Management.

[5] Raz T and Michael E 2001 Use and benefits of tools for project risk management. Int. J. Proj. Manag. 19: 9-17

[6] JG Perry 1986 Risk management? An approach for project managers. Int. J. Proj. Manag. 4: 211-216

[7] Cooper D F 2005 Project risk management guidelines: managing risk in large projects and complex procurements. London: Wiley.

[8] Kutsch E and Hall M 2010 Deliberate ignorance in project risk management. Int. J. Proj. Manag. 28: 245-255.

[9] Isaac I 1995 Training in risk management. Int. J. Proj. Manag. 13: 225-229

[10] Giles E L, Brennan M, Albogamy A and Dawood N 2015 Development of a client-based risk management methodology for the early design stage of construction processes: applied to the KSA. Eng. Construct. Archittect. Manag. 22: 493-515 
[11] Dey P K 2001 Decision support system for risk management: a case study. Manag. Decis 39: 634-649

[12] Nasirzadeh F, Afshar A and Khanzadi M 2007 System dynamics approach to optimum response selection in construction project risks. In: 3rd International Project Management Conference, Iran University of Science and Technology, Tehran

[13] Ali Hatefi M, Seyedhoseini S M and Noori S 2007 Risk response actions selection. Int. J. Appl. Manag. Technol. 5: 385-408

[14] Sato T and Hirao M 2013 Optimum budget allocation method for projects with critical risks. Int J. Proj. Manag. 31: 126-135

[15] Muriana C and Vizzini G 2017 Project risk management: A deterministic quantitative technique for assessment and mitigation. Int. J. Proj. Manag. 35: 320-340

[16] Zhang Y 2016 Selecting risk response strategies considering project risk interdependence. Int. J. Proj. Manag. 34: 819-830

[17] Gładysz B, Skorupka D, Kuchta D, Duchaczek A 2015 Project risk time management-a proposed model and a case study in the construction industry. Procedia Comput. Sci. 64: 24-31

[18] Nguyen T-H, Marmier F and Gourc D 2013 A decisionmaking tool to maximize chances of meeting project commitments. Int. J. Prod. Econ. 142: 214-224

[19] Fang C, Marle F and Zio E 2011 An integrated framework for the optimization of project risk response plan under resource constraints with genetic algorithm. In: Qual. Reliab. Risk, Maintenance, Saf. Eng. (ICQR2MSE), 2011 Int. Conf. pp 856-861

[20] Taylan O, Bafail A O, Abdulaal R M S and Kabli M R 2014 Construction projects selection and risk assessment by fuzzy AHP and fuzzy TOPSIS methodologies. Appl. Soft Comput. 17: $105-116$

[21] Chang C W 2014 Develop a ranking algorithm for the green building project. Qual. Quant. 48: 911-921

[22] Vinodh S and Swarnakar V 2015 Lean Six Sigma project selection using hybrid approach based on fuzzy DEMATELANP-TOPSIS. Int. J. Lean Six Sigma 6: 313-338

[23] Shih H-S, Shyur H-J and Lee E S 2007 An extension of TOPSIS for group decision making. Math Comput Model 45: 801-813

[24] Dawood N 1998 Estimating project and activity duration: a risk management approach using network analysis. Construvt. Manag. Econ. 16: 41-48

[25] Öztaş A and Ökmen Ö 2005 Judgmental risk analysis process development in construction projects. Build. Environ. 40: $1244-1254$

[26] Roger C and Petch J 1999 Uncertainty \& Risk Analysis: A practical guide from Business Dynamics PricewaterhouseCoopers, MCS

[27] McKenna C K 1980 Quantitative methods for public decision making. New York: McGraw-Hill College

[28] Ling F Y Y and Hoi L 2006 Risks faced by Singapore firms when undertaking construction projects in India. Int. J. Proj. Manag. 24: 261-270

[29] Mojtahedi S M H, Mousavi S M and Makui A 2010 Project risk identification and assessment simultaneously using multi-attribute group decision making technique. Saf. Sci. 48: 499-507
[30] Shebob A, Dawood N and Shah R K 2012 Development of a methodology for analysing and quantifying the impact of delay factors affecting construction projects. J. Construct. Eng. Proj. Manag. 2: 17-29

[31] Goh C S, Abdul-Rahman H and Abdul Samad Z 2013 Applying risk management workshop for a public construction project: case study. J. Construct. Eng. Manag. 139: 572-580

[32] Nasir D, McCabe B and Hartono L 2003 Evaluating risk in construction-schedule model (ERIC-S): construction schedule risk model. J. Construct. Eng. Manag. 129: 518-527

[33] Islam M S, Nepal M P, Skitmore M and Attarzadeh M 2017 Current research trends and application areas of fuzzy and hybrid methods to the risk assessment of construction projects. Adv. Eng. Informatics 33: 112-131

[34] Kumar C, Yadav D K 2015 A probabilistic software risk assessment and estimation model for software projects. Procedia Comput. Sci. 54: 353-361

[35] Baker S, Ponniah D and Smith S 1999 Risk response techniques employed currently for major projects. Construct. Manag. Econ. 17: 205-213

[36] Ben-David I and Raz T 2001 An integrated approach for risk response development in project planning. J. Oper. Res. Soc. 52: $14-25$

[37] Hillson D 2002 Extending the risk process to manage opportunities. Int. J. Proj. Manag. 20: 235-240

[38] Ward S and Chapman C 2003 Transforming project risk management into project uncertainty management. Int. J. Proj. Manag. 21: 97-105

[39] Dey P K and Ogunlana S O 2004 Selection and application of risk management tools and techniques for build-operatetransfer projects. Ind. Manag. Data Syst. 104: 334-346

[40] Kasap D and Kaymak M 2007 Risk identification step of the project risk management. Picmet 07 Portl. Int. Cent. Manag. Eng. Technol. pp 2116-2120. 10.1109/picmet.2007.4349543

[41] Zhang J, Cai M, Li X and Mu Z 2011 Prioritizing highway tunnel risk factors with AHP method. In: Inf. Sci. Technol. (ICIST), 2011 Int. Conf. pp 1205-1207

[42] Dey P K 2012 Project risk management using multiple criteria decision-making technique and decision tree analysis: a case study of Indian oil refinery. Prod. Plan. Control 23: 903-921

[43] Oke A E and Ugoje O F 2013 Assessment of rework cost of selected building projects in Nigeria. Int. J. Qual. Reliab. Manag. 30: 799-810

[44] Acebes F, Pajares J, Galán J M and López-Paredes A 2014 A new approach for project control under uncertainty. Going back to the basics. Int. J. Proj. Manag. 32: 423-434

[45] Shanmugapriya S and Subramanian K 2015 Structural equation model to investigate the factors influencing quality performance in Indian construction projects. Sadhana 40: 1975-1987.

[46] Pfeifer J, Barker K, Ramirez-Marquez J E and Morshedlou N 2015 Quantifying the risk of project delays with a genetic algorithm. Int. J. Prod. Econ. 170: 34-44

[47] Wang J and Yuan H 2016 System dynamics approach for investigating the risk effects on schedule delay in infrastructure projects. J. Manag. Eng. 4016029

[48] Zhao X, Hwang B-G and Gao Y 2016 A fuzzy synthetic evaluation approach for risk assessment: a case of Singapore's green projects. J. Clean Prod. 115: 203-213 
[49] Mohammadipour F and Sadjadi S J 2016 Project cost-quality-risk tradeoff analysis in a time-constrained problem. Comput. Ind. Eng. 95: 111-121

[50] Wanjari S P and Dobariya G 2016 Identifying factors causing cost overrun of the construction projects in India. Sädhana 41: 679-693

[51] Jung W and Han S H 2017 Which risk management is most crucial for controlling project cost? J. Manag. Eng. 33(5): 22-25

[52] Malekitabar H, Ardeshir A, Sebt M H, Stouffs R and Teo E A L 2018 On the calculus of risk in construction projects: contradictory theories and a rationalized approach. Saf. Sci. 101: $72-85$
[53] Shen L 1997 Project risk management in Hong Kong. Int. J. Proj. Manag. 15: 101-105

[54] Frimpong Y, Oluwoye J and Crawford L 2003 Causes of delay and cost overruns in construction of groundwater projects in a developing countries; Ghana as a case study. Int. J. Proj. Manag. 21: 321-326

[55] Sambasivan M and Soon Y W 2007 Causes and effects of delays in Malaysian construction industry. Int. J. Proj. Manag. 25: 517-526

[56] Wang S Q, Tiong R L K, Ting S K and Ashley D 2000 Evaluation and management of foreign exchange and revenue risks in China's BOT projects. Construct. Manag. Econ. 18: $197-207$ 